\title{
Evaluating the quality of contemporary global governance: A theoretical and analytical framework
}

Tim Cadman ${ }^{1}$

University of Southern Queensland

Toowoomba

Queensland 4350

Australia

tim.cadman@usq.edu.au

$+61419628709$

Word Count: 9, 790

\section{Abstract}

Non-state interests have become increasingly active in international policy making, most notably in the environmental arena, and a wide variety of new institutions exist alongside established intergovernmental forums. When it comes to analysing the quality and legitimacy of governance practice across these divergent institutions, existing state-centric theories only partially apply. In order to determine and compare institutional performance across these multiple systems, it has become necessary for scholars to develop more cross-disciplinary approaches than before. In the light of these developments, this article presents a new way of classifying governance, and argues that its contemporary manifestations are best understood as representing varying models of social-political interaction built around 'participation as structure' and 'deliberation as process'. Using a hierarchical framework of principles, criteria and indicators, it is then possible to evaluate these attributes and consequently determine governance quality. The implications and broader application of such an analytical approach are discussed in a concluding section.

Keywords: governance quality, legitimacy, participation, deliberation 


\section{Introduction}

It might perhaps be an overstatement to say that current governance studies are at a crisis point, but they have certainly reached something of a crossroads. When it comes to explaining contemporary developments, conventional disciplines are no longer applicable in their classical form. This is particularly the case with international relations (IR). The previously orthodox viewpoint that geopolitical cooperation occurs almost exclusively within the sphere of intergovernmental regimes comprised of intergovernmental agreements that are pursued in the context of state-based authority is now considered as being largely out of touch. ${ }^{2}$ The regime concept, particularly influential in recent IR theory, is beginning to be replaced by the more relevant idea of multi-level governance. ${ }^{3}$ A body of theory in the field of comparative politics has arisen over the past decade and half, which argues for a broader understanding of state and non-state relations than those explained by traditional top-down, command-control models of regime-based state authority. Modern governance is portrayed as essentially socialpolitical in nature, and defined as "more or less continuous processes of interaction between social actors, groups and forces and public or semi-public organizations, institutions or authorities." Interaction is key, and is identified as a series of 'co'-arrangements between state and non-state actors, more oriented towards collaborative approaches to problem solving. ${ }^{5}$ In such models the transmission of information and knowledge and its valuation by those involved plays a central role; and deliberation rather than directives has become an alternative mechanism of dealing with the complexity and ambiguity of political and social problems. ${ }^{6}$ These new systems now sit alongside traditional, more legalistic, mechanisms. ${ }^{7}$ Scholars of public administration interpret these as representing a form of 'new governance' and although this term is itself the subject of various interpretations, it can be broadly understood as "a new process of governing.", 
Governance is also becoming increasingly understood in terms of its expression not only on the national and international levels, but at all spatial scales. ${ }^{9}$ Contemporary environmental governance articulates this trend particularly strongly, and is exemplified by the interactions that occur between decentralised networks made up of multiple actors functioning at all levels. ${ }^{10}$ Given the trans-boundary nature of environmental issues in particular, divergent groups are drawn together both within and beyond the traditional democratic confines of the nation state in a kind of "vigourous pluralism." such developments, and in order to make governance more effective, there have also been calls for researchers to think about institutional design more creatively. ${ }^{12}$ In these circumstances it has been further argued that the application of a range of ideas from several traditions may prove useful. ${ }^{13}$ However, the comment has also been made that there are problems with developing normative theories of governance. ${ }^{14}$

This article is a response to these observations, and makes use of a range of materials from across the field of governance studies, environmental politics, and the experiences gained in the field of forest governance specifically. Forest governance provides one of the best spaces available to study the emergence of new modes of governance that have arisen in response to globalisation. ${ }^{15}$ This is because it is in the forest sector specifically that some of the most extensive and innovative experiments in 'new' governance - of which forest certification is one of the most interesting - exist. ${ }^{16}$ Forest governance consequently provides one of the most useful lenses through which to scrutinise "the increasing tendency for collaboration in many sectors where political and economic trade-offs also exist.",17

Being aware of the difficulties associated with such an approach, four important problems confronting the development of new theories are identified. Firstly, there are conflicts over the classification of the various types of contemporary global governance. Secondly, there are inconsistencies within the sub-disciplines of political science regarding 
institutional legitimacy, whence it is derived, and the relationship between legitimacy and quality of governance. Thirdly, while there is general agreement regarding the governance arrangements that underpin legitimate institutions (such as accountability, transparency, and so forth), there is no agreement as to how these attributes relate one to another. Finally, there is at present no cross-disciplinary method to evaluate governance quality. In response to these theoretical challenges the article identifies an alternative means of classifying global governance, and presents a new analytical framework for understanding and evaluating quality of governance and by implication, institutional legitimacy.

\section{Classifying governance}

Beyond the recognition that there is something 'new' about contemporary governance, there has been little else to hold all the discrete definitions together. This has led to calls for the development of a typology that accounts for the various structures and processes through which participants interact. ${ }^{18}$ Numerous scholars have risen to this challenge in recent times, but this has resulted in a number of conflicting governance typologies, depending on the discipline, and date of authorship. As studies have progressed and the impacts of the growth of governance have been absorbed by previously discrete fields, it is now possible to see an increasing degree of convergence, although differences remain. ${ }^{19}$ As a result attempts have been made to identify and place the major concepts of governance within a broader analytical framework as a means of organising the literature. ${ }^{20}$ These are outlined in Table 1 below. Arts presents the most concise typology, since he provides way of looking at contemporary governance that more efficiently captures the essence of the differences between 'old' governance (purely state-centric) and the gradations associated with 'new' models (state and/or non-state, non-state and hybrid), as well as recognising the increasing integration between previously discrete schools of thought. ${ }^{21}$ This is a useful contribution to 
distinguishing between different forms of governance, but it is essentially one-dimensional, and only reinforces the divide between governance types. Since each type confronts - and is affected - by similar globalising forces, it is more useful to look at some of the common themes that impact upon all types of contemporary governance, to see whether these themes can be used as a basis for a more integrated approach.

\section{Table 1}

Firstly, rather than presenting global governance as existing only within rigid definitional sets, it would be better to conceive it as a "dynamic interplay" between state and non-state actors. ${ }^{22}$ In addition to a shift in locality away from the nation state to multiple sites, the nature of contemporary authority, or sovereignty, has also changed. The old state-centric exercise of authority and the new power of non-state interests sit on two ends of a continuum. ${ }^{23}$ Secondly, given the changes to the nation state as the sole sphere of authority regardless of its continuing existence and contribution to global politics - there is an active discussion across the literature about the practice of democracy in a globalised world. ${ }^{24}$ Democracy on a global level occurs in venues of collective action that are becoming increasingly pluralised, more community-based, and less under the direct organisation of the state. ${ }^{25}$ Deliberative democracy is particularly relevant, given the lack of formal supranational authority other than the member-states model of the United Nations, and a growing preference for partnerships and multi-stakeholder processes. It also conveniently avoids the "conceptual trap of state-centric notions of democracy." ${ }^{26}$ Here, deliberation is to be contrasted with more traditional, state-centric approaches, where interests are aggregated and compete with each other. These two modes have been characterised as consisting of cooperative versus competitive political interaction. ${ }^{27}$ Finally, within governance theory itself, the discussion is also about the 'old' and the 'new', which is made more complicated by the fact that it is easier to distinguish between 'old' than the many and varied 'new' governance types. ${ }^{28}$ In practice, 
divergent forms of governance also appear alongside each other in the global policy arena. This is demonstrated, for example, by the existence of older, intergovernmental multilateral agreements, alongside newer, market-based instruments. ${ }^{29}$ Consequently innovation provides a useful benchmark against which contemporary governance can be measured.

These three factors are interpreted here as influencing the type of governance expressed in a given institution. Each institution will also sit in different places along the continuum in relation to each of these factors. This interplay can be expressed conceptually by way of a three-dimensional attribute space (see Figure 1 below). By allocating some form of simple rating system (for example, low, medium and high) on both ends of the continuum, it is also possible, on the basis of empirical data, to determine the extent to which these themes are expressed in existing institutions, and to plot those institutions in three dimensions. $^{30}$

\section{Figure 1}

This typological approach has the advantage of being able to locate multiple institutions in the one conceptual framework for the purposes of comparative analysis. As the discussions above have indicated, there is a considerable variety in the governance systems utilised by institutions at the global level. The approach adopted here regarding classification therefore provides a means of locating various institutions in relation to one another, not by their specific institutional type, but rather by three of the most significant forces at play on all systems of governance at the global level. Understanding these variations may also assist in determining whether there is a link between these broad institutional factors and quality of governance.

\section{Quality and legitimacy of governance}


Recognition has grown that governance theory and analysis is grounded within the normative assumption that structure and process is fundamental to understanding the quality of interactions between participants in contemporary global institutions. ${ }^{32}$ This emerges in the material of the early 1990s, with a clear distinction made between governing, understood as a process of coordination, steering, influencing or 'balancing' social-political interactions; and governance, interpreted as the structure that emerges in a social-political system as result of interaction. $^{33}$ This idea re-emerges a decade later in terms of 'governance as structure', understood as the models utilised by various institutions (and repeating some of the debates surrounding typologies of governance), and 'governance as process', again referring to the idea of steering or coordinating. ${ }^{34}$ The interaction between structure and process as a whole could be interpreted as comprising the 'co' arrangements referred to above, and relates to participation within an institution's structure and deliberation via its processes, which together describe the nature of collaboration in 'new' governance. It is this interaction that results in substantive outcomes, such as the formulation of criteria, or setting of standards. ${ }^{35}$ Structure, process and substantive outcomes are seen as interrelated components necessary for the solving of problems within contemporary governance. ${ }^{36}$ Together, they have been identified as the key determinants of 'governability', understood as the overall capacity of a system to govern itself. ${ }^{37}$

But, even if quality of governance is conceived of in these terms, it is nevertheless still necessary to address the issue of legitimacy, since there is disagreement between governance theorists as to whence legitimacy is derived. Two theories currently dominate: 'input' and 'output' legitimacy. Input legitimacy is derived from the consent of those being asked to agree to the rules, and concerning such procedural issues as the democratic arrangements underpinning a given system. ${ }^{38} \mathrm{An}$ input-oriented perspective implies that the procedures and processes by which a system's policies are developed result in legitimacy. ${ }^{39}$ Democracy, for 
example, has been identified as an input-oriented, procedural aspect of legitimacy, derived from compliance with rules agreed to by the majority for taking collectively binding decisions. ${ }^{40}$ This analysis has led scholars to look further into input legitimacy, connecting it more specifically to interest representation and accountability and transparency, rather than simply equating it to democracy. ${ }^{41}$ As a result, there have been recommendations for more participation and a greater emphasis on processes of deliberation in governance systems. ${ }^{42} \mathrm{On}$ the basis of empirical studies, it has been noted that the more inclusive and the greater its levels of participation, the more effective the system, in contrast to those that are more exclusive. ${ }^{43}$ On a global level, this leads to the conclusion that the network-like nature of contemporary governance allows for the participation of multiple actors, whose interactions can deliver better coordination and performance than traditional models. ${ }^{44}$

Output legitimacy is derived from the efficiency of rules, or criteria for 'good' governance, and demonstrated by substantive outcomes. ${ }^{45}$ In contrast to input legitimacy, the implication is that "a political system and specific policies are legitimated by their success." This view argues that increasing input legitimacy through expanding interest representation and deliberation, can increase costs, and therefore has an impact on efficiency (outputlegitimacy). ${ }^{47}$ The comparative politics and public administration literature in particular tends to look at legitimacy in terms of the quality - often synonymous with both the efficiency and effectiveness - of a given system. ${ }^{48}$ Quality on this view is derived from the substantive outputs, of a given system, such as standards. ${ }^{49}$ This is typified within such organisations as the World Bank, which has adopted a standards-based approach, insisting on the need for particular criteria of 'good' governance as a basis for lending. ${ }^{50}$ Output legitimacy, as well as being linked to effectiveness, is also now being analysed in terms of problem solving capacity. ${ }^{51}$ In this regard, a shift in institutional thinking has been noted towards increasing efforts aimed at changing behaviour amongst actors. Although a change in emphasis towards 
behaviour change may not actually solve a given problem, it nevertheless allows for the consideration of side effects as well as intentional results. This is essentially an analytical distinction between outputs (agreements) and outcomes (behaviour change). Greater stress is placed on examining the causal mechanisms, particularly the nature of participation, by which regimes affect the behaviour of both state and non-state actors. ${ }^{52}$

Both perspectives establish a relationship between the effectiveness of a given institution and a range of commonly identified governance arrangements that underpin them; the emphasis on which is the most significant depends largely on the critical theory adopted. ${ }^{53}$ But in view of the globalising forces at play, and since international events can impact on state affairs and vice-versa, there is also a general increase in the crossover between disciplines. ${ }^{54}$ Whatever the scholarly perspective however, structure, process, outputs and outcomes are interrelated, and may be conveniently married to both input and output legitimacy, since input legitimacy concerns itself with the structures and processes of governance, whilst output legitimacy is more interested in outputs and outcomes. Bearing this in mind, this interrelationship can be expressed figuratively (see Figure 2 below).

\section{Figure 2}

Legitimacy can consequently be determined both according to the principles of democracy on the one hand and efficiency and effectiveness on the other. ${ }^{55}$ Additionally, recognising the social-political nature of contemporary governance emphasised in the literature, it is also necessary to further conceive of legitimacy in sociological terms. ${ }^{56}$ Quality of governance in this broader context should therefore be understood in terms of social-political interactions within the structures and processes of an institution and the outcomes they generate; the more balanced these elements, the more governable the system. ${ }^{57}$

\section{Governance arrangements}


Now that the relationship between structure, process and legitimacy is understood, it is worth looking at the specific attributes that apply to quality of governance. A wide range of scholars has commented at length on the various arrangements underpinning governance. The term 'governance arrangement' has come to be used to refer to a range of specific mechanisms influencing the nature of the interaction between the participants involved in collective-action solutions. ${ }^{58}$ These institutional arrangements, identified across the fields of governance theory, have a bearing on governance quality, and are discussed in the following four sections immediately below.

\section{Interest representation: inclusiveness, equality and resources}

Interest representation has been identified as a major challenge in contemporary global governance. ${ }^{59}$ The inclusion, or inclusiveness, of stakeholders, is generally associated with interest representation, and is seen as a crucial dimension underlying institutional variation at a global level. ${ }^{60}$ This has led to a recognition that the complexities of governance brought about by globalisation call for a reinvention of interest representation in post-modern public administration. ${ }^{61}$ The European Commission for example identifies inclusiveness as a principle of 'good' governance. ${ }^{62}$ Inclusiveness has been broken down into two constituent parts, access and weight. ${ }^{63}$ Access denotes the number of actors bounded, or affected, by a given policy, and the extent to which they actively participate in developing its content. Weight refers to the extent to which influence is distributed among the active participants. Inclusiveness therefore varies, depending on the degree of access and weight a potential participant might have. ${ }^{64}$ Governance has been described as being inclusive as when parties affected by regulation are involved in associated decision making processes, and those impacted upon by a given rule, are both formally and informally listened to. ${ }^{65}$ Democratic theorists stress further that all those affected by decision making should be included equally, 
and they identify a relationship between inclusion and equality, and exclusion and inequality. ${ }^{66}$ Effective interest representation in global governance also requires significant resources. These are generally only available to well-endowed organisations, residing in the more privileged parts of the world. Lack of resources can be offset when associations collaborate, however, and in this regard at least, networks have been identified as having the potential to play a beneficial role. If the problems surrounding how networks are themselves resourced can be overcome, such structures have the potential to impact positively on global governance. ${ }^{67}$ Scholars further point to the need for economic-technical capacity (money and expertise) as well as institutional support as a structural framework condition for organisations seeking to develop effective policy within decision making processes that include both public and private actors. ${ }^{68}$

\section{Accountability and transparency}

Accountability has become a central aspect of the quality of governance debate, since the rise of new actors and new institutions has necessitated a reconfiguration of existing democratic mechanisms for holding participants to account. ${ }^{69}$ It is seen as being both an internal and external requirement of good governance. ${ }^{70}$ There is a need for a better meshing together of internal and external accountability measures, posing a number of unresolved normative questions. ${ }^{71}$ Some scholars see that defining what constitutes a robust accountability system is a major problem facing advocates of new governance, and have problems envisaging any serious contenders to the state as a source of democratic accountability. ${ }^{72}$ Consequently, there have been calls for properly adapted principles of accountability to satisfy normative democratic criteria as world politics generally lack universally accepted values and institutions. $^{73}$ Other commentators recommend a standards-based approach for global institutions of governance as a solution to demonstrating accountability. ${ }^{74}$ Greater freedom of 
information is seen as potentially compensating for the remoteness of global processes from democratic accountability. ${ }^{75}$ In this context, the external accountability of decision makers is to the public at large, and is linked to what appears as a related attribute, transparency, expressed in terms of public access to information and decision making procedures. ${ }^{76}$ Transparency plays a role both in the participation of interests from the inception of a governance system or policy process (ex ante) and in the public scrutiny of decision making (ex post).$^{77}$ It is effectively a precondition for effective accountability, since it is impossible to hold an institution to account if its regulatory operations are not open to public view. ${ }^{78}$ Internally, formal structures and clearly defined rules are required for each level, otherwise transparency can be lost, and policy making predetermined. ${ }^{79}$ In short, how the responsibility of participating actors should be ensured in non-state, non-elected structures continues to be the subject of some debate. ${ }^{80}$

\section{Decision making}

There is general recognition that as governance continues to develop at a global level, procedural arrangements are likely to be based more and more upon commonly agreed rules and practices. ${ }^{81}$ Governance itself is increasingly multi-level, undermining traditional concepts of community and representation, generating a form of decision making, which is occurring in forums that in addition to their democratic expression are also, as indicated above, more deliberative in procedural style. ${ }^{82}$ Current intergovernmental systems are seen as lacking the necessary processes to cope with greater degrees of non-state participation. ${ }^{83}$ This has led to the conclusion that without existing institutional arrangements being changed in favour of more productive interaction, built around consensus, global environmental negotiations will continue to produce inadequate results. ${ }^{84}$ Such "processes of discursive consensus formation", would be along the lines of the theories of Habermas. ${ }^{85}$ EU regime 
scholars have examined whether decision making operating on a consensual or majority basis is more effective. ${ }^{86}$ Anecdotal case studies of environmental processes in the US, echoing those in the EU, indicate that agreement is often reached by consensus (understood as total agreement) during the working stages of negotiation, reverting to a majority vote at the end. ${ }^{87}$ However, commentators critical of current policymaking have noted an almost obsessive trend to consensus within new modes of regulatory governance. ${ }^{88}$ Criticisms include the definitional inconsistencies of consensus, which can be defined as both constituting unanimity, or as a decision everybody can live with. ${ }^{89}$

Policy-making, implementation and enforcement inevitably involve conflict amongst interested parties. ${ }^{90}$ When conflict occurs within negotiations, or as a result of complaints over procedure, several sources identify the need for dispute-resolution mechanisms. ${ }^{91}$ The inability to resolve conflicts has been identified as a key indicator of governance failure. ${ }^{92}$ Interestingly, it is in the arena of environmental governance where some of the most extensive use of these processes is made. ${ }^{93}$ In cases of environmental dispute resolution, it has been noted that the consensus developed through mediation can bring separate interests closer together. ${ }^{94}$ Such an approach would again consist of "discursive procedures" for dispute settlement through the solving of problems cooperatively. ${ }^{95}$ Conflict should therefore not be seen as a negative aspect of governance. ${ }^{96}$ So long as it does not encompass irreconcilable issues such as matters of religion or ideology for example, conflict can be managed, even if it is ongoing. Indeed, the ongoing nature of "muddling through" a particular conflict may even set the stage for the next round of engagement and negotiation. ${ }^{97}$

\section{Implementation}

In order to determine whether a given policy objective has been implemented effectively, it is necessary to trace the final effects of a given policy and its related programmes. ${ }^{98} \mathrm{EU}$ scholars 
stress the relationship between implementation and compliance. ${ }^{99}$ Implementation is "the process of putting...commitments into practice." ${ }^{100}$ Compliance is "a state of conformity" between a specified rule and an affected party's behaviour. ${ }^{101}$ Compliance is consequently seen as a proxy for effectiveness. ${ }^{102}$ Effectiveness is also presented as a measure of an institution's problem solving capacity. ${ }^{103}$ This has led one scholar to note, that "an environmental regime is successful when it solves the problem that led to its creation", although this should not be overstated. ${ }^{104}$ Successful implementation therefore relates to both behavioural- and problem solving effectiveness. ${ }^{105}$ Notably, it is argued, an institutional approach to problem solving that incorporates a degree of flexibility results in governance systems that are more resilient in the face of external change and may even benefit from it. Non-resilient systems on the other hand are vulnerable to change. ${ }^{106}$

\section{Evaluating governance quality}

\section{Hierarchical consistency and institutional expression}

Before immediately proceeding with a discussion on how to evaluate governance quality, there remains a further problem in need of resolution: the hierarchy of relationships between governance arrangements. Scholars have tended to focus on individual elements of 'good' governance - the most notable being accountability and transparency - but they have generally not examined the nature of the relationship between those arrangements as a whole (between interest representation and decision making, for example). In terms of actual governance practice different emphasis is placed on specific aspects of these arrangements, depending on institutional focus or attitudes, resulting in competing governance frameworks between systems. In the forestry sector for example, there have been various attempts to develop baseline standards, or thresholds, to assess the legitimacy of competing systems, but

these have yet to gain universal acceptance. ${ }^{107}$ Governance scholars in this particular field 
have also inadvertently contributed to the problem by making use of various sets of criteria in their evaluations of quality of governance. ${ }^{108}$ This lack of consistency is not confined to forestry. Criteria and indicators are often used as interchangeable terms when discussing quality of governance. ${ }^{109}$ As a consequence, there is at present no simple assessment template for evaluating governance quality. For the purposes of understanding the nature of the relationship between the various governance arrangements discussed above, a consistent hierarchical framework of PC\&I for the determination of governance quality is presented here, acknowledging existing practices in the field of environmental management, and forest governance in particular. ${ }^{110}$ The intention behind the placement of these attributes within such a framework is to ensure that they are located at the right level, to allow for a top-down analysis of principles via criteria and subsequently to indicators. Consistency in this context relates to the correct location within the framework: it is important that elements are placed at the appropriate level and do not overlap or duplicate those at another, and are linked back to the appropriate parameter at a higher level (see Table 2 immediately below). ${ }^{111}$

\section{Table 2}

In this context, a principle is defined as a fundamental rule, which serves as a basis for reasoning, the objective of such reasoning being to ascertain the function of the total system in respect to explicit elements of governance. A principle can also express a certain perspective regarding a specific aspect of the system as it interacts, in this context, with the overall governance system. ${ }^{112}$ Here the perspective, or attitude adopted regarding participation as the fundamental structural aspect of governance is that it should be meaningful. This term is frequently associated with participation in much of the literature, and serves here as a normative, qualitative descriptor. ${ }^{113}$ The second principle, referring to the deliberative, procedural, aspects of governance, has been ascribed the term productive as its descriptor. ${ }^{114}$ In this context the principle is more than a statement about the democratic legitimacy of a 
process, as it refers both to the quality of deliberations, as they occur within the system, as well as the quality of the outcomes, or products, of those deliberations.

Criteria are parameters functioning at the next level below principles, and demonstrate compliance with them in relation to specific aspects or states of the system. They are intended to facilitate the assessment of principles that would otherwise be ideational and nonmeasurable. ${ }^{115}$ A criterion can also be described as "a category of conditions or processes" against which, a system can be assessed. ${ }^{116}$ Criteria are themselves not usually capable of being measured directly, however, but are formulated to provide a determination on the degree of compliance. ${ }^{117}$ They are consequently linked to indicators, which are hierarchically lower, and which may consist of either quantitative or qualitative parameters, and do describe conditions indicative of the state of the governance system as they relate to the relevant criterion. $^{118}$

Any discussion regarding the criteria associated with the principles of meaningful participation and productive deliberation therefore occurs simultaneously with their associated indicators. In the framework presented here, the structural principle of meaningful participation is demonstrated through two criteria, interest representation and organisational responsibility. The representation of interests within a governance system is a fundamental aspect of participation. In the discussion of the governance literature presented above interest representation has been linked to three elements of governance, which function on the indicator level: inclusiveness, demonstrating who participates in a governance system; equality, indicating the extent to which participating interests are balanced; and resources, referring to the economic, technical or institutional capacity of a participant to represent their interests within the system. The second criterion, organisational responsibility is comprised of two indicators, accountability and transparency, which are usually treated together in the literature, and refer to the extent to which the behaviour of participating organisations can be 
both called to account both inside the institution and externally by the public at large, as well as being visible, or open, to scrutiny by other actors within the institution, and beyond.

The procedural principle of productive deliberation is demonstrated through two criteria, decision making and implementation. Three indicators are linked to decision making: democracy, not referring to a specific mode of democracy, but rather the extent to which a system can be deemed to be functioning democratically; agreement, referring to the presence of collective decision making arrangements, such as voting, or consensus; and dispute settlement, indicating the system's capacity to manage conflict when there is no agreement, or there are challenges to decisions made. Three indicators are linked to implementation: behaviour change, used to determine whether the implementation of agreements, or substantive outcomes results in changed behaviour regarding the problem that the system was created to address; problem solving, referring to the extent to which the system has solved the problem it was created to address; and durability, capturing the two related elements of adaptability and flexibility, as well as longevity. The way in which this hierarchical relationship between principles, criteria and indicators is expressed institutionally is examined further in the context of Figure 3 below.

\section{Institutional relationship between governance arrangements}

It should be noted that the PC\&I method of evaluation suggested here is not without its critics. Indicators in particular have been labelled a "pathological corruption of the reductionist approach", and are based on voodoo science. ${ }^{119}$ This has led to the conclusion that indicators are best used in a controlled manner to account for the critical dimensions of a system, and only in conjunction with other simultaneous views. ${ }^{120}$

In order to address these concerns, Figure 3 immediately below situates the hierarchical relationship between PC\&I within their specific institutional context. 


\section{Figure 3}

This has the effect of mapping the critical dimensions of a governance system onto the institutional qualities that the PC\&I are seeking to evaluate. Figure three should also be viewed as a more elaborate way of understanding 'participation as structure' and 'deliberation as process', as presented in Figure 2. It should be noted in this representation, however, that implementation is related to both structure and process, since both play a role in developing the outputs that need to be implemented. This difference from the hierarchical framework of Table 2 arises from the attempt to understand governance from an alternative, but simultaneous viewpoint, which takes a greater account of the complexity of the interactions within the system. ${ }^{121}$

Finally, it remains for these elements to be evaluated. Table 3 below presents a matrix against which institutional performance can be ascertained.

\section{Table 3}

Performance is determined at the indicator level, and ranked low, medium and high. For the purposes of comparative analysis, performance is also recorded in numerical terms (from one to three points) with a reference value, or norm, of 2 (or 'medium' rating). ${ }^{122}$ Following the hierarchical assessment framework of PC\&I, the cumulative values of the relevant individual indicators demonstrate the degree of fulfilment at the criterion level; these criteria in turn form the cumulative basis for determining compliance at the principle level; at both the criterion and principle levels a conventional pass/fail target value of $50 \%$ may be used to determine performance. ${ }^{123}$

A warning has been sounded in studies of global governance that conversion of verbal (low, medium, high) into numerical descriptions can create the illusion of scientific credibility. ${ }^{124}$ These warnings also concern whether qualitative data can be applied to develop quantitative results. ${ }^{125}$ There can also be further problems when indicators are combined to 
provide aggregated scores. ${ }^{126}$ This can lead to a situation where a system scores poorly in one indicator, only to meet the threshold at the criterion level, or fails to meet the criterion level threshold, whilst still meeting requirements at a principle level. This is acknowledged as a potential distortion of the results, and it is accepted that precision in the analytical framework presented here is not always possible. However, when applying this framework to actual institutions, making use of a range of sources of information for determining performance such as primary (i.e. institutional), and secondary (i.e. academic and/or critical sources) as well as key informant interviews could partially address this issue by providing for a 'triangulated' critical analysis, not reliant on a single data source. ${ }^{127}$ There is also scope for quantitative analysis through larger cohorts of informants, and quantitative analysis of performance issues that are raised in secondary sources.

\section{Conclusions}

This paper has briefly examined the construction of global governance, and argued the case that participation and deliberation are integral to the structures and processes of effective and legitimate governance in contemporary global institutions. Specifically, using a detailed framework of governance-related principles, criteria and indicators for evaluating governance quality, it has gone beyond the relatively random selection and application of criteria previously used to determine governance quality elsewhere. Contemporary governance is expressed in a number of divergent, and at times, competing, models. Processes aimed at developing national governmental responses to a given problem may place an entirely different emphasis on certain governance attributes than private or civic initiatives. Whilst all will share similar components, and at times provide complementary approaches, they may vary markedly in their policy objectives. Indeed, these observations apply even within apparently similar regulatory models, and may be reinforced, for example, by the rivalry 
between market competitors. Research undertaken by the author, and using the framework presented in this paper, has shown that in the area of forest management in particular there is considerable variation not only in the types of institution in the policy domain, but also in the quality of governance between institutions, state and non-state, and between individual market-driven systems. ${ }^{128}$

Although the approach presented here allows for consistent analysis across institutions, any empirical studies into the quality of global governance would require examination of a wide range of case studies across a broad spectrum of institutional types to determine if the framework is applicable in multiple contexts. Contemporary governance often functions on the micro, meso and macro levels, from the local to the global. The methodology adopted in this study implies that consistently formulated hierarchies of PC\&I have the potential to be applied at all spatial levels. ${ }^{129}$ It would therefore be helpful to determine if assessment can be scaled down to encompass those aspects of global governance that occur at the national and sub-national levels. In addition, in terms of the indicators-based approach to evaluating governance performance, it may also be necessary to extend investigations to a finer level of detail to include specific verifiers for each indicator. ${ }^{130}$ Rather than relying on anecdotal information, this would provide a uniform set of information by which each indicator could be evaluated. ${ }^{131}$ Data collection would be more consistent, and reliant on specific information; for example, in the case of transparency, one verifier might be the public availability of certain types of information (for example board minutes, or the existence of public disclosure statements along the lines of the Global Reporting Initiative). Furthermore, each indicator is at present equally weighted within the relevant criterion. In the case of interest representation, for example, this places the same degree of significance on the provision of resources for participation as the inclusiveness of participation. However, it has been noted that the scoring and weighting of indicators and determining their relative 
importance is a subjective exercise, and this may prove counter-productive. ${ }^{132}$ Finally, there are also some possible problems with the calibration of the evaluative matrix. With a simple 'low-medium-high' rating of governance performance, scores have the potential to be almost too close to call. This might be resolved by increasing the sophistication of calibration. Investigating the application of PC\&I in a range of other fields may be helpful in this regard. Consequently, the analytical approach presented here should be seen as developing some insights into, and contributing to a revision of, some of the theories of contemporary governance, but is not at this stage definitive in its own right.

Nevertheless, caveats notwithstanding, the value of a typological framework that concentrates on institutional classification on the basis of authority, democracy, and innovation, is that it avoids the current divide between theoretical approaches, which argue either for the ongoing supremacy of the state, or emphasise the non-state aspects of contemporary governance. Secondly, the way in which the different aspects of a governance system have been attached to either structure or process and linked to related PC\&I also provides an opportunity for the development of a programmatic method to evaluate institutional performance in a relatively simple manner, and identify areas in need of improvement.

A further value of the PC\&I approach to evaluation is that it also allows for the creation of standards that can serve as a reference for monitoring, assessment and reporting. ${ }^{133}$ It may be possible to develop a standard out of the framework used in this study that could be applied to the practice of governance at the global, national and local levels. In view of the hierarchical inconsistencies of the governance arrangements in the governance literature, and the institutional 'self-certification' currently in place, such a standard is essential. As the world comes to grips with a range of global problems, and social political interactions increasingly occur within contexts beyond the territorial borders of the democratic state, 
governance standards have the potential to become a primary method by which legitimacy can be guaranteed. Such standards would make it easier for potential participants to determine whether they should engage in a given process or not. It would avoid the uncertainty that currently exists over the legitimacy of some systems, and whether to lend them credibility by participating.

The analytical framework presented here may also be applicable in a range of environmental policy arenas, one of the most topical being climate change. In this case, an exploration of the relationship between structure, process and problem-solving capacity would be very useful. It would be helpful to undertake a comparative analysis as to whether market-based environmental governance systems are more, or less, effective than other models (such as multilateral environmental agreements), and which specific market models voluntary versus mandatory emissions-based trading, for example - contain the better problem solving approaches. Another related area, such as social responsibility, already demonstrates a range of certification systems and intergovernmental approaches, and is a likely candidate for evaluation against such models and standards. Fairtrade and other commodity labelling programmes, as well as organic certification more generally, also spring to mind.

Lastly, in terms of potential benefits, it would also be interesting to see whether the framework can be applied further afield to economic institutions such as the World Bank, the World Trade Organisation and the International Monetary Fund. In view of the current economic crisis, an institutional analysis focussing on governance performance across the global financial sector might assist greatly in the current efforts for regulatory reform. Whether there are causal links between market failure and governance failure, and whether a deliberative approach contributes to a more effective institution than one dominated by single or dual interests, would, in this context, be extremely valuable hypotheses to test. 


\section{Endnotes}

${ }^{1}$ Tim Cadman MA is a graduate of Girton College, Cambridge, and recently submitted his doctoral thesis on global governance to the School of Government in the Faculty of Arts at the University of Tasmania. He currently holds a post-doctoral teaching and research fellowship in sustainable business and research development in the Faculty of Business at the University of Southern Queensland.

2 J. Rosenau, "Change, Complexity and Governance in a Globalising Space", in J. Pierre (ed.), Debating Governance: Authority, Steering and Democracy (Oxford and New York: Oxford University Press, 2000) pp. $167-168$.

${ }^{3}$ Kees van Kersbergen and Frans van Waarden, '“Governance' as a Bridge Between Disciplines: Crossdisciplinary Inspiration Regarding Shifts in Governance and Problems of Governability, Accountability and Legitimacy", European Journal of Political Research, Vol. 43 (2004), p. 149.

${ }^{4}$ J. Kooiman, "Social-Political Governance: Introduction" in J. Kooiman (ed.) Modern Governance: New Government Society Interactions (London: Sage, 1993) pp. 1-8 at p. 3.

5 J. Kooiman, "Findings, Speculations and Recommendations", in Kooiman, ibid., pp. 250-251.

${ }^{6}$ M. Van Vliet, "Environmental Regulation of Business: Options and Constraints for Communicative Governance”, in Kooiman, ibid, pp. 108-109.

${ }^{7}$ Daniel Fiorino, "Rethinking Environmental Regulation: Perspectives on Law and Governance", The Harvard Environmental Law Review Vol. 23 No. 2 (1999), pp. 441-469.

${ }^{8}$ Rod Rhodes, Understanding Governance: Policy Networks, Governance, Reflexivity and Accountability. (Buckingham: Open University Press, 1997), p. 48 (emphasis in original).

${ }^{9}$ Anne Mette Kjaer, Governance (Cambridge and Malden MA: Polity Press, 2004), pp. 3-5; Dianne Perrons, Globalization and Social Change: People and Places in a Divided World. (London: Routledge, 2004), p. 253. ${ }^{10}$ Peter Haas, "UN Conferences and Constructivist Governance of the Environment”, Global Governance, Vol. 8, No. 1 (2002), pp. 73-91, at p. 74; P. Glück, J. Rayner and B. Cashore, "Changes in the Governance of Forest Resources", in G. Mery, R. Alfaro, M. Kaninnen, and M. Lobovikov (eds.), Forests in the Global Balance Changing Paradigms (Helsinki: IUFRO, 2005), p. 51.

${ }^{11}$ W. M. Lafferty and J. Meadowcroft, "Democracy and the Environment: Prospects for Greater Congruence", in W. M. Lafferty and J. Meadowcroft (eds.) Democracy and the Environment: Problems and Prospects (Cheltenham and Lyme: Edward Elgar, 1996), p. 257.

12 M. Zürn and M. Koenig-Archibugi, “Conclusion II: Modes and Dynamics of Global Governance”, in M. Koenig-Archibugi and M. Zürn (eds.) New Modes of Governance in the International System: Exploring Publicness, Delegation and Inclusion (London: Palgrave Macmillan, 2006), p. 251; see also G. Stoker, "The Challenge of Urban Governance", in J. Pierre (ed.), Debating Governance: Authority, Steering and Democracy (Oxford: Oxford University Press, 2000) p. 107.

13 J. Kooiman, "Societal Governance: Levels, Models, and Orders of Social-Political Interaction", in Pierre, ibid, pp. 161-162.

${ }^{14}$ B. Guy Peters, "Governance and Comparative Politics", in Pierre, ibid, pp. 50-51. 
B. Arts, "Non-state Actors in Global Governance: New Arrangements Beyond the State", in KoenigArchibugi and Zürn, op. cit., p. 178.

16 Glück, Rayner and Cashore, op. cit., pp. 55-64.

${ }^{17}$ Christine Overdevest, "Codes of Conduct and Standard Setting in the Forest Sector: Constructing Markets for Democracy?” Relations Industrielles/Industrial Relations, Vol. 59, No. 1 (2004), p. 192.

18 James Rosenau, Distant Proximities: Dynamics Beyond Globalization. (Princeton and Oxford: Princeton University Press, 2003), p. 394.

19 Arts, op. cit., p. 179.

${ }^{20}$ M. Koenig-Archibugi, “Introduction: Institutional Diversity in Global Governance”, in Koenig-Archibugi and Zürn, op. cit., pp. 12-15.

21 Arts, op. cit., p. 179.

22 J. G. Ruggie, “Taking Embedded Liberalism Global: The Corporate Connection”, in D. Held and M. KoenigArchibugi (eds.), Taming Globalisation: Frontiers of Governance (Cambridge: Polity Press, 2003), p. 95.

23 Andrew Jordan, Rüdiger K. W. Wurzel and Anthony Zito, “The Rise of 'New' Policy Instruments in Comparative Perspectives: Has Governance Eclipsed Government?” Political Studies, Vol. 53 (2005), pp. 492494.

24 David Held, Anthony G. McGrew, David Goldblatt and Jonathan Perraton, Global Transformations: Politics, Economics and Culture. (London: Polity Press, 1999), pp. 447- 449.

25 Michael E Warren, "What Can Democratic Participation Mean Today?” Political Theory, Vol. 30, No. 5 (2002), p. 682.

26 Karin Bäckstrand, "Multi-Stakeholder Partnerships for Sustainable Development: Rethinking Legitimacy, Accountability and Effectiveness", European Environment, Vol. 16 (2006), p. 293.

27 Iris Marion Young, Inclusion and Democracy. (Oxford: Oxford University Press, 2000), pp. 1-26. See also John Dryzek, Discursive Democracy. (Cambridge: Cambridge University Press, 1990) and Patrizia Nanz and Jens Steffek, "Assessing the Democratic Quality of Deliberation in International Governance: Criteria and Research Strategies", Acta Politica, Vol. 40, No. 3 (2005), p. 370.

${ }^{28}$ Peters, op. cit., pp. 50-51.

29 Jordan, Wurzel and Zito, op. cit., pp. 492-494.

${ }^{30}$ Koenig-Archibugi, op. cit., pp. 15-16, following P. Lazarsfeld and A. H. Barton, "Qualitative Measurement in the Social Sciences: Classification, Typologies and Indices" in D. Lerner and H.D. Laswell (eds.) The Policy Sciences (Stanford: Stanford University Press, 1951), pp. 155-192.

31 William Reuben, "The Role of Civic Engagement and Social Accountability in the Governance Equation", Social Development Notes, Vol. 75 (2003), p. 2.

${ }^{32}$ Kooiman, “Societal Governance: Levels, Models, and Orders of Social-Political Interaction”, op. cit., p. 163.

33 Kooiman, "Findings, Speculations and Recommendations", op. cit., pp. 258-259.

34 Jon Pierre and B. Guy Peters, Governance, Politics and the State. (Macmillan Press: Basingstoke and London, 2000), pp. 14-24. 
35 Kooiman, "Findings, Speculations and Recommendations", op. cit., p. 260

36 J. Kooiman, "Social-Political Governance: Introduction" in J. Kooiman (ed.) Modern Governance: New Government-Society Interactions (London: Sage, 1993), pp. 1-8 at p. 5. See also Robert Falkner, "Private Environmental Governance and International Relations: Exploring the links”, Global Environmental Politics, Vol. 3, No. 2 (2003), pp. 72-87. For a discussion on the interplay between civil society, globalisation, forest management and governance, see also Gordon M. Hickey and John L. Innes, "Monitoring Sustainable Forest Management in Different Jurisdictions”, Environmental Monitoring and Assessment, Vol. 108 (2005), pp. 241-260. For a detailed investigation of 'new' forest governance, see Glück, Rayner and Cashore, op. cit., pp. $55-64$.

${ }^{37}$ Kooiman, "Findings, Speculations and Recommendations", op. cit., p. 259.

${ }^{38}$ Kjaer, Governance, p. 12, citing Fritz W. Scharpf, Games Real Actors Play. Actor-Centered

Institutionalism in Policy Research. (Boulder CO: Westview Press, 1997), p. 153.

${ }^{39}$ Van Kersbergen, and Van Waarden, op. cit., p. 158.

${ }^{40}$ Kjaer, op. cit., p. 12.

${ }^{41}$ Bäckstrand, op. cit., pp. 292-293.

${ }^{42}$ Kjaer, op. cit., pp. 13-14 and p. 191.

43 Jørgen Wettestad, "Designing Effective Environmental Regimes: The Conditional Keys" Global Governance, Vol. 7, No. 3 (2001), p. 320.

44 Peter Haas, "Addressing the Global Governance Deficit", Global Environmental Politics, Vol. 4, No. 4 (2004), pp. 1-15, at p. 1.

${ }^{45}$ Kjaer, op. cit, p. 12.

${ }^{46}$ Van Kersbergen and van Waarden, op. cit., p. 158.

47 Stijn Smismans, Law, Legitimacy, and European Governance: Functional Participation in Social Regulation. (Oxford: Oxford University Press, 2004), pp. 459-460.

48 See for example Conor O’Dwyer and Daniel Ziblatt, "Does Decentralisation Make Government More Efficient and Effective?" Commonwealth \& Comparative Politics, Vol. 44, No. 3 (2006), pp. 326-343, Fara Azmat, "Good Governance and Market-based Reforms: a Study of Bangladesh", International Review of Administrative Sciences, Vol. 71, No. 4 (2005), pp. 625-638, Mateus Tomsic and Urban Vehovar, "Kakovost Vladanja v Starih in Novih Clanicah Evropske Unije" (The Quality of Governance in Old and New EU MemberStates), Teorija in Praksa, Vol. 43, Nos. 3-4 (2006), pp. 386-405.

49 Kooiman, "Findings, Speculations and Recommendations”, op. cit., pp. 259-260.

${ }^{50}$ Kjaer, op. cit, pp. 172-187.

${ }^{51}$ Bäckstrand, op. cit., pp. 292-293.

52 O. R. Young, "Hitting the Mark: Why are Some Environmental Agreements More Effective Than Others?" Environment, Vol. 20 (1999), reproduced in D. Zaelke, D. Kainaru and E. Kružíková (eds.), Making Law Work: Environmental Compliance \& Sustainable Development (London: Cameron May, 2005), volume 1, pp. 189-191. 
${ }^{53}$ Koenig-Archibugi, op. cit., pp. 7-13.

${ }^{54}$ Kjaer, op. cit., pp. 3-5.

55 Christopher Elliott, Forest Certification: A Policy Perspective. (Bogor: Center for International Forestry

Research, 2000), p. 23. Effectiveness describes overall performance in relation to an institution's objectives or programmes, and efficiency denotes the cost and rate by which inputs translate into outputs (ibid. p. 23).

${ }^{56}$ S. Bernstein and B. Cashore, "Nonstate Global Governance: Is Forest Certification a Legitimate Alternative to a Global Forest Convention?" in J. J. Kirton and M. J. Treiblock (eds.), Hard Choices, Soft Law: Combining Trade, Environment, and Social Cohesion in Global Governance (Aldershot: Ashgate Press, 2004), p. 41.

${ }^{57}$ Kooiman, “Societal Governance: Levels, Models, and Orders of Social-Political Interaction” op. cit., p. 159.

${ }^{58}$ Koenig-Archibugi, op. cit., Footnote 13, p. 24.

59 J. E. Stiglitz, “Globalization and Development”, in D. Held and M. Koenig-Archibugi, op. cit., p. 61.

${ }^{60}$ Koenig-Archibugi, op. cit., p. 13.

${ }^{61}$ Rhodes, op. cit., p. 198.

${ }^{62}$ Smismans, op. cit., p. 26.

${ }^{63}$ Koenig-Archibugi, op. cit., p. 14.

${ }^{64}$ Koenig-Archibugi, ibid, pp. 14-15.

${ }^{65}$ Koenig-Archibugi, ibid, p. 15, citing M. Zürn and J. Neyer, "Conclusions - the Conditions of Compliance”, in M. Zürn and C. Joerges (eds.) Law and Governance in Post-National Europe: Compliance Beyond the Nation State (Cambridge Unversity Press: Cambridge), 2005 p. 199.

${ }^{66}$ Young, Inclusion and Democracy, op. cit., pp 11-12.

67 Jan A. Scholte, “Civil Society and Democratically Accountable Global Governance”, Government and Opposition, Vol. 39, No. 2, pp. 223-225.

68 Michael Mason, Environmental Democracy. (New York: St Martin’s Press, 1999), pp. 72-73. See also Martin Jänicke, "Conditions for Environmental Policy Success: An International Comparison”, The Environmentalist, Vol. 12 (1992), pp. 47-58, "Democracy as a Condition for Environmental Policy Success: the Importance of Non-institutional Factors", in W. M. Lafferty and J. Meadowcroft (eds.) Democracy and the Environment: Problems and Prospects, op. cit., pp. 71-85; "The Political System's Capacity for Environmental Policy", in M. Jänicke and H. Weidner (eds.) Successful Environmental Policy: A Critical Evaluation (Springer: Berlin, 1997).

${ }^{69}$ Held, Goldblatt and Perraton, op.cit., p. 447.

${ }^{70}$ Rosenau, “Change, Complexity and Governance in a Globalising Space”, in Pierre, op. cit., p. 193.

${ }^{71}$ R. O Keohane, "Global Governance and Democratic Accountability”, in Held and Koenig-Archibugi, op. cit., p. 137.

72 Pierre and Peters, op. cit., pp. 195-196.

${ }^{73}$ Keohane, op. cit., pp. 132-133. 
${ }^{74}$ A. Kölliker, "Conclusion 1: Governance and Public Goods Theory”, in Koenig-Archibugi, and Zürn, op. cit., p. 208 .

75 Stiglitz, op. cit., at p. 63.

76 D. Kerwer, "Governing Financial Markets by International Standards", in Koenig-Archibugi, and Zürn, op. cit., p. 83 .

${ }^{77}$ Smismans, op. cit., p. 22.

${ }^{78}$ Scholte, op. cit., pp. 211-233.

79 Gerald Berger, "Reflections on Governance: Power Relations and Policy Making in Regional Sustainable Development", Journal of Environmental Policy and Planning, Vol. 5, No. 3 (2003), pp. 224-225.

80 Mark Callanan, "Institutionalizing Participation and Governance? New Participative Structures in Local Government in Ireland”, Public Administration, Vol. 83, No. 4 (2005), pp. 910-911.

${ }^{81}$ Keohane, op. cit., p. 139.

82 D. Held, "Executive to Cosmopolitan Multilateralism”, in Held and Koenig-Archibugi op. cit., pp. 174-177.

${ }^{83}$ Lawrence Susskind, Environmental Diplomacy: Negotiating More Effective Global Agreements. (New York and Oxford: Oxford University Press, 2004), p. 61; Ivana Zovko, "International Law-Making for the Environment: A Question of Effectiveness", in Marko Berglund (ed.) International Environmental Lawmaking and Diplomacy Review 2005 (Joensuu: University of Joensuu Department of Law, 2006), p. 128, citing Robert Churchill and Geir Ulfstein, "Autonomous Institutional Arrangements in Multilateral Environmental Agreements: A Little noticed Phenomenon in International Law", American Journal of International Environmental Law, Vol. 94 (2000), p. 623.

84 Susskind, op. cit., p. 7.

85 Meadowcroft and Lafferty, op. cit., p. 257.

${ }^{86}$ Wettestad, op. cit., pp. 318-331.

87 James E. Crowfoot and Julia M. Wondolleck, Environmental Disputes: Community Involvement in Conflict Resolution. (Washington and Clovello: Island Press, 1990), p. 261; Wettestad, op. cit., pp. 318-331

${ }^{88}$ Cary Coglianese, Is Consensus an Appropriate Basis for Regulatory Policy? (Cambridge MA: Harvard University Press, 2000).

${ }^{89}$ Coglianese, op. cit., pp. 4-6.

90 Lisa Blomgren Bingham, Rosemary O’Leary and Tina Nabatchi, "Legal Frameworks for the New Governance: Processes for Citizen Participation in the Work of Government”, National Civic Review, Vol. 94, No. 1 (2005), pp. 54-56.

${ }^{91}$ Van Vliet, op. cit., p. 111; Errol Meidinger, "The Administrative Law of Global Private-public Regulation: The Case of Forestry", The European Journal of International Law, Vol. 17, No. 1 (2006), pp. 47-87 and pp. 25-27; Elinor Ostrom, Governing the Commons: the Evolution of Institutions for Collective Action. (Cambridge: Cambridge University Press, 1990), p. 90.

92 Stoker, op. cit., pp. 100-105. 
93 Bingham, O’Leary and Nabatchi, op. cit., pp. 54-56.

${ }^{94}$ Van Vliet, op. cit., pp. 107-108.

95 John Dryzek, The Politics of the Earth: Environmental Discourses. (New York: Oxford University Press, 1990), p. 200.

${ }^{96}$ Stoker, op. cit, p. 105, citing Albert Hirschman, "Social Conflicts as Pillars of Democratic Market Societies", A Propensity to Self-Subversion (Cambridge MA: Harvard University press, 1995).

97 Ibid., p. 105.

${ }^{98}$ Pierre and Peters, op. cit., p. 31.

99 Ellen Mastenbroek, “EU Compliance: Still a 'Black Hole’?” Journal of European Public Policy, Vol. 12, No. 6 (2005), pp. 1103-1120.

${ }^{100}$ Zaelke, Durwood and Kružíková, op. cit., p. 22, citing O. R. Young and M. A. Levy, “The Effectiveness of International Environmental regimes", in O. R. Young (ed) The Effectiveness of International Environmental Regimes: Causal Connections and Behavioural Mechanisms (Cambridge MA: MIT Press, 1999), pp. 3-4.

101 Ibid., p. 22, citing K. Raustiala and A-M. Slaughter, "International Law, International Relations and Compliance", in W. Carlsnaes (ed.) Handbook of International Relations (London: Sage, 2002), p. 539 (2002).

102 Ibid., p. 23, citing R. B. Micthell, “Compliance Theory: An Overview” in J. Cameron, J. Werksman and P. Roderick (eds.) Improving Compliance with International Environmental Law (London: Earthscan, 1996), p. 25 .

103 Ibid., p. 22.

104 Ibid., p. 189.

105 Jon Birger Skjærseth, Olav Schram Stokke and Jørgen Wettestad, "Soft Law, Hard Law, and Effective Implementation", Global Environmental Politics, Vol. 6, No. 3 (2006), p. 105, footnote 11, following Arild Underdal, “The Concept of Regime Effectiveness”, Cooperation and Conflict, Vol. 27 (1992), pp. 227-240.

106 Carl Folke, Thomas Hahn, Per Olsson and Jon Norberg, “Adaptive Governance of Social-Ecological Systems", Annual Review of Environment and Resources, Vo. 30 (2005), pp. 463-464.

107 David Humphreys, Log Jam: Deforestation and the Crisis of Global Governance. (London: Earthscan, 2006), p. 136. Humphreys is referring to forest management certification.

108 This issue is discussed by Humphreys, Log Jam, p. 135, citing F. Gale, "Caveat Certificatum: The Case of Forest Certification", in T. Princen, M. Maniates and K. Conca (eds.), Confronting Consumption (Cambridge MA: MIT Press, 2002), p. 288.

${ }^{109}$ Nanz and Steffek, op. cit., at p. 370.

110 This approach is adapted from Erik M. Lammerts van Beuren and Esther M. Blom, Hierarchical Framework For The Formulation Of Sustainable Forest Management Standards. (Leiden: The Tropenbos Foundation, 1997) pp. 5-9.

${ }^{111}$ Ibid., pp. 5-9. 
112 Ibid., p. 34 .

113 This term first appears in the United Nations Declaration on the Right to Development, adopted by General Assembly resolution 41/128 of 4 December 1986 (John Gaventa, "Making Rights Real: Exploring Citizenship, Participation and Accountability", Journal of International Development Studies, Vol. 33 No. 2 (2002), pp. 111.

114 See for example John Dryzek and Valerie Braithwaite, “On the Prospects for Democratic Deliberation: Values Analysis Applied to Australian Politics” Political Psychology, Vol. 21, No. 2 (2002), pp. 241-266.

${ }^{115}$ Lammerts van Beuren and Blom, op. cit., p. 20.

116 Montréal Process, Criteria and Indicators for the Conservation and Sustainable Management of Temperate and Boreal Forest Ecosystems (Unknown location: Montréal Process, 1999), second edition, p. 5.

${ }^{117}$ Lammerts van Beuren and Blom, op. cit., pp. 22 and 34.

118 Ibid., p. 22.

119 Roger Bradbury, “Are Indicators Yesterday's News?” in Institute of Environmental Studies (ed.), Tracking

Progress: Linking Environment and Economy Through Indicators and Accounting Systems. (Sydney: The University of New South Wales, 1996) reproduced at http://www.tjurunga.com/biography/roger-papers.html, accessed 15/09/07), p. 6.

${ }^{120}$ Ibid., p. 7.

${ }^{121}$ Ibid.,, pp. 8-9 (in relation to climate-, rather than governance systems).

122 "A norm is the reference value of the indicator and is established for use as a rule or a basis for comparison. By comparing the norm with the actual measured value, the result demonstrates the degree of fulfilment of a criterion and of compliance with a principle" (Lammerts van Beuren and Blom, op. cit., p. 24).

123 "A reference value to strive for is called a target value" (Ibid., p. 24).

${ }^{124}$ Nanz and Steffek, op. cit., p. 373.

125 Ibid., p. 373, citing David Beetham, Sarah Bracking, Ian Kearton, and Stuart Weir, International IDEA Handbook on Democracy Assessment (Den Haag: Kluwer 2002).

${ }^{126}$ Ibid., p. 373.

127 Phillip H. Pattberg, "The Forest Stewardship Council: Risk and Potential of Private Forest Governance", Journal of Environment and Development, Vol. 14, No. 3 (2005), p. 365, following Thomas A. Schwandt, Qualitative Inquiry: A Dictionary of Terms (Thousand Oaks: Sage, 1997). ${ }^{128}$ Timothy M. Cadman, Quality, Legitimacy and Global Governance: A Comparative Analysis of Four

Forest Institutions. Thesis submitted in fulfilment of the requirements for the degree of Doctor of Philosophy, (University of Tasmania, January 2009).

${ }^{129}$ Lammerts van Beuren and Blom, op. cit., p. 7. It is noted however that: "specific spatial levels may require additional principles particularly relevant to that level" (ibid.).

130 "A verifier is the source of information for the indicator, or for the reference value of the indicator", ibid., p. 35. 
131 Ibid., p. 25.

132 Ibid., p. 29.

${ }^{133}$ Ibid., p. 34. 
Table 1 Three typologies of governance 1997-2006

\begin{tabular}{|c|c|c|c|c|c|}
\hline Public Policy & Form & $\begin{array}{l}\text { International } \\
\text { Relations }\end{array}$ & Form & $\begin{array}{l}\text { 'Analytic' } \\
\text { (Arts) }\end{array}$ & Form \\
\hline Centralised & $\begin{array}{l}\text { Government has } \\
\text { control }\end{array}$ & Top-down & $\begin{array}{l}\text { Traditional } \\
\text { governmental } \\
\text { \& inter- } \\
\text { governmental } \\
\text { relations } \\
\text { (including } \\
\text { business) }\end{array}$ & Old & $\begin{array}{l}\text { State-steered } \\
\text { (top-down, } \\
\text { command- } \\
\text { control) }\end{array}$ \\
\hline Minimal state & $\begin{array}{l}\text { Less } \\
\text { government, } \\
\text { more } \\
\text { privatisation }\end{array}$ & Bottom-up & $\begin{array}{l}\text { Informal civil } \\
\text { society } \\
\text { initiatives }\end{array}$ & New & $\begin{array}{l}\text { New modes } \\
\text { (self-regulation, } \\
\text { etc. - public- } \\
\text { private) }\end{array}$ \\
\hline Corporate & $\begin{array}{l}\text { Directed and } \\
\text { controlled by } \\
\text { companies }\end{array}$ & Market & $\begin{array}{l}\text { Multiple } \\
\text { players using } \\
\text { formal \& } \\
\text { informal } \\
\text { market-based } \\
\text { mechanisms }\end{array}$ & All & $\begin{array}{l}\text { New and old } \\
\text { mechanisms for } \\
\text { procuring public } \\
\text { goods (public, } \\
\text { private \& mixed) }\end{array}$ \\
\hline $\begin{array}{l}\text { New public } \\
\text { management } \\
(N P M)\end{array}$ & $\begin{array}{l}\text { Private sector } \\
\text { practices in the } \\
\text { public sector }\end{array}$ & Network & $\begin{array}{l}\text { Formal state, } \\
\text { civil society, } \\
\text { business } \\
\text { alliances }\end{array}$ & Normative & $\begin{array}{l}\text { Programmes to } \\
\text { renew } \\
\text { management } \\
\text { (good } \\
\text { governance, } \\
\text { new public } \\
\text { management \& } \\
\text { corporate } \\
\text { governance - } \\
\text { public \& private) }\end{array}$ \\
\hline 'Good' & $\begin{array}{l}\text { Practices of } \\
\text { NPM and liberal } \\
\text { democratic } \\
\text { values }\end{array}$ & Side-by-side & $\begin{array}{l}\text { Informal } \\
\text { cooperative } \\
\text { arrangements } \\
\text { between state } \\
\& \text { non-state } \\
\end{array}$ & & \\
\hline $\begin{array}{l}\text { Socio- } \\
\text { cybernetic }\end{array}$ & $\begin{array}{l}\text { Social-political } \\
\text { interaction }\end{array}$ & Mobius-web & $\begin{array}{l}\text { Intricate, } \\
\text { overlapping } \\
\text { mixed } \\
\text { arrangements } \\
\text { ("end-state" of } \\
\text { contemporary } \\
\text { governance) }\end{array}$ & & \\
\hline $\begin{array}{l}\text { Self-organising } \\
\text { networks }\end{array}$ & $\begin{array}{l}\text { Inter-dependent } \\
\text { actors/ agencies } \\
\text { delivering } \\
\text { services }\end{array}$ & & & & \\
\hline
\end{tabular}

Sources: Rhodes (1997), Rosenau (2003), Arts (2006) 
Table 2 Hierarchical framework for the assessment of governance quality

\begin{tabular}{|c|c|c|}
\hline Principle & Criterion & Indicator \\
\hline \multirow[t]{5}{*}{ "Meaningful participation" } & \multirow[t]{3}{*}{ Interest representation } & Inclusiveness \\
\hline & & Equality \\
\hline & & Resources \\
\hline & \multirow[t]{2}{*}{ Organisational responsibility } & Accountability \\
\hline & & Transparency \\
\hline \multirow[t]{6}{*}{ "Productive deliberation" } & \multirow[t]{3}{*}{ Decision making } & Democracy \\
\hline & & Agreement \\
\hline & & Dispute settlement \\
\hline & \multirow[t]{3}{*}{ Implementation } & Behavioural change \\
\hline & & Problem solving \\
\hline & & Durability \\
\hline
\end{tabular}


Table 3 Evaluative matrix of governance quality

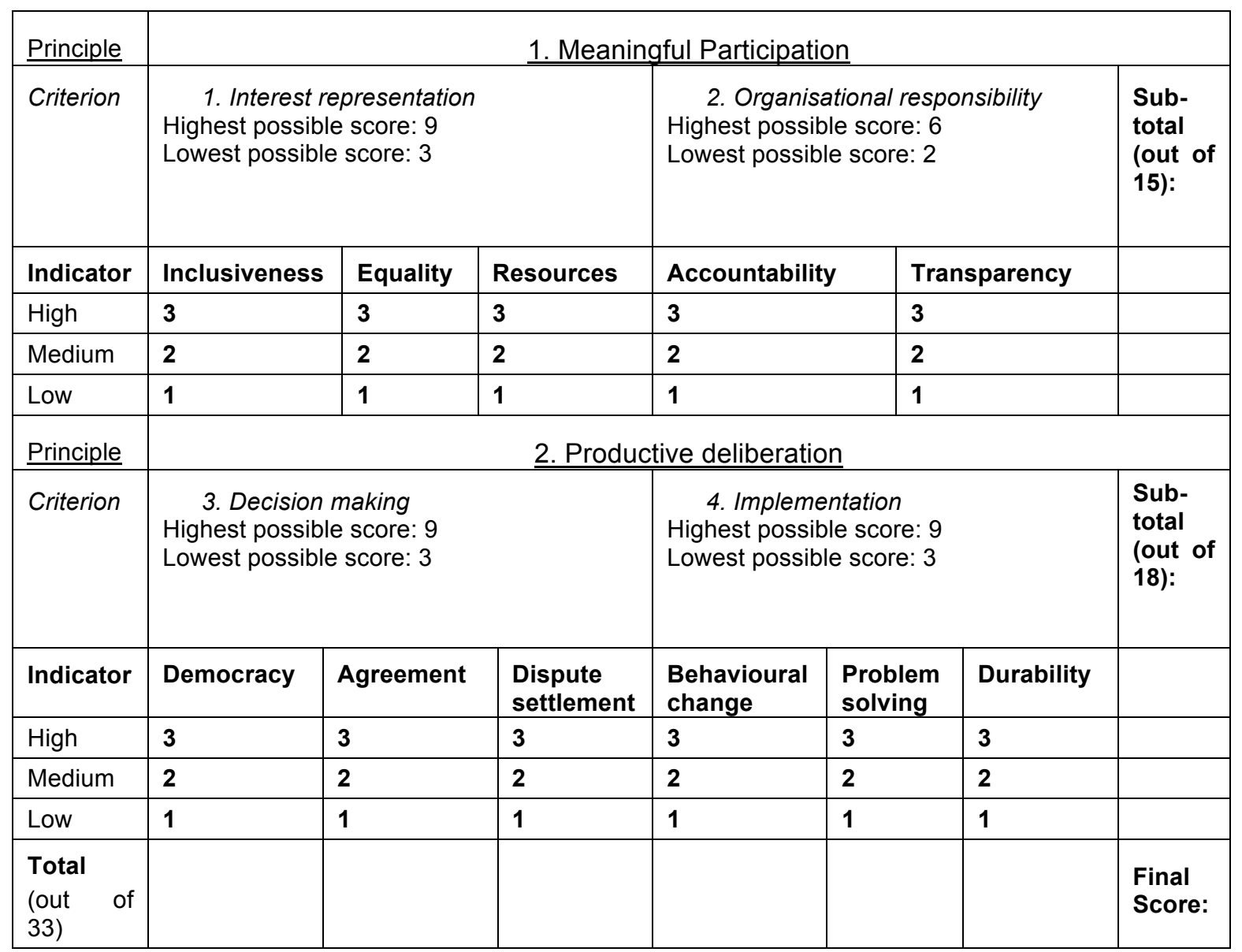


Figure 1 Attribute space for the classification of four hypothetical governance institutions

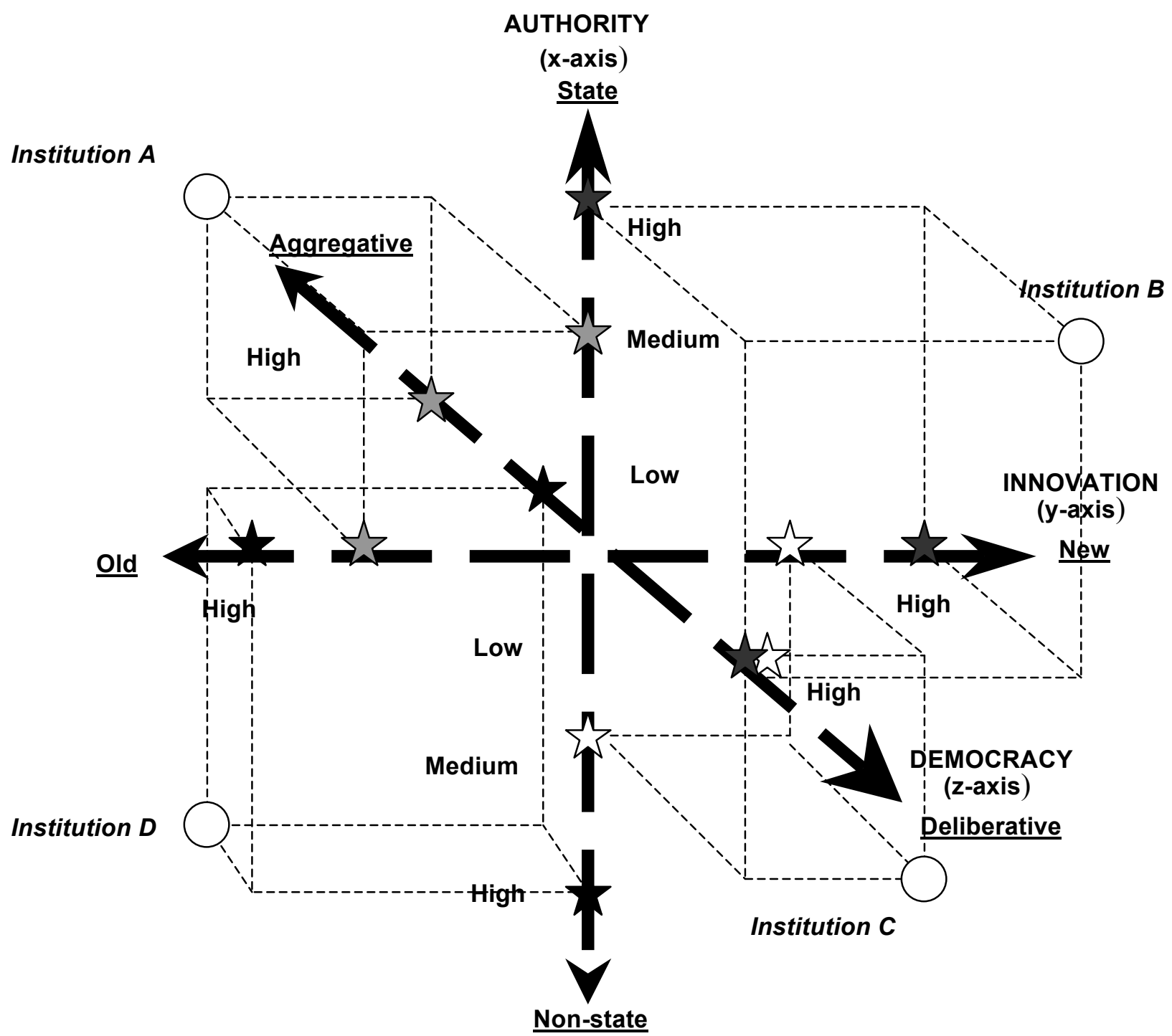

\section{KEY}

WInstitution A $\begin{aligned} & \text { Authority - state (high); Democracy - deliberative (medium); Innovation - new } \\ & \text { (high) }\end{aligned}$

WInstitution B $\begin{aligned} & \text { Authority - state (medium); Democracy - aggregative (medium); } \\ & \text { Innovation - old (medium) }\end{aligned}$

$\hat{W}$ Institution C Authority - non-state (medium); Democracy - deliberative (medium); Innovation - new (medium)

finstitution D $\begin{aligned} & \text { Authority - non-state (high); Democracy - aggregative (low); Innovation - old } \\ & \text { (high) }\end{aligned}$

Sources: adapted from Koenig-Archibugi (2006), Reuben (2003). ${ }^{31}$ 
Figure 2 Conceptual model of contemporary global governance

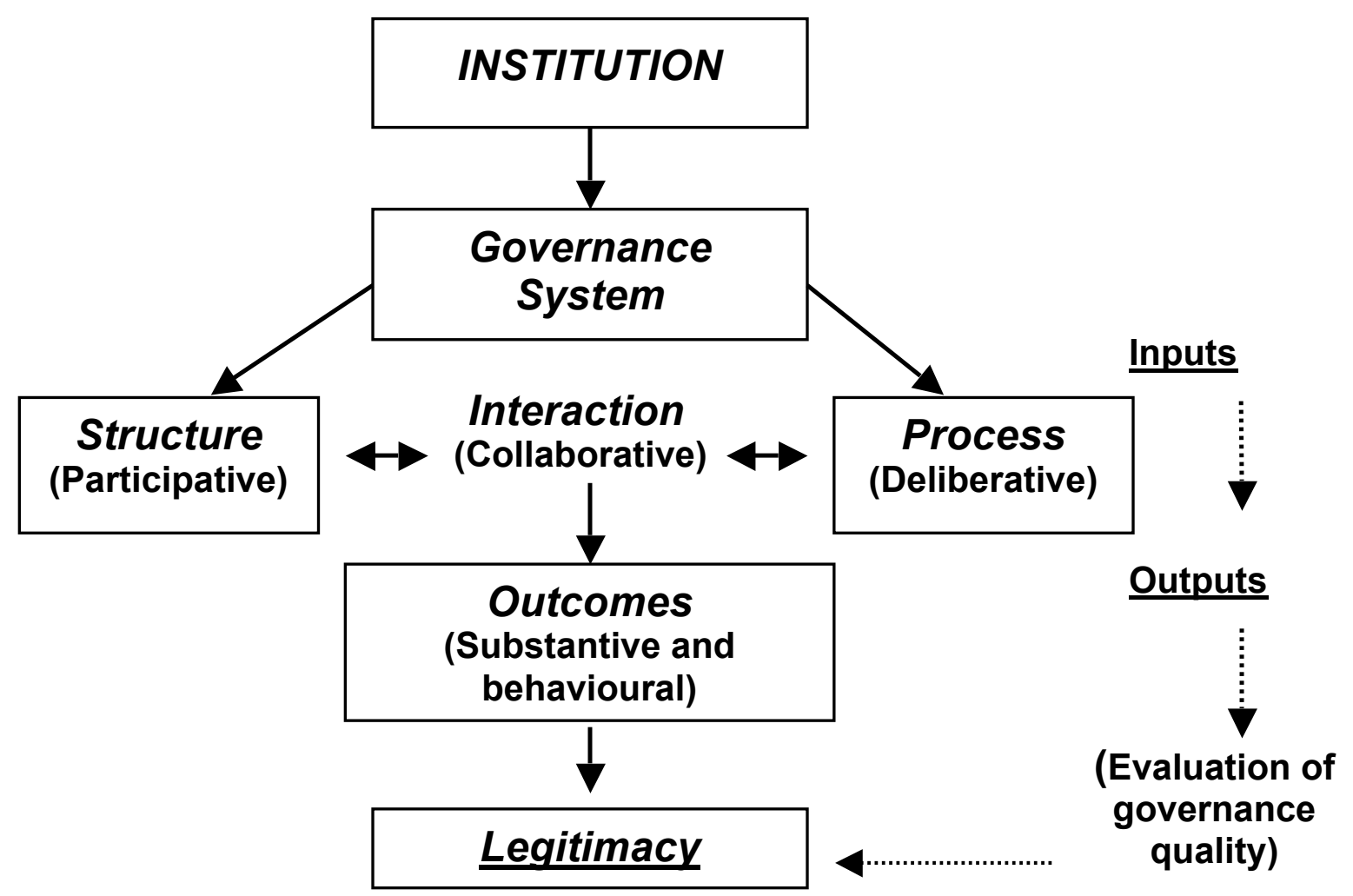


Figure 3 Institutional model of governance quality

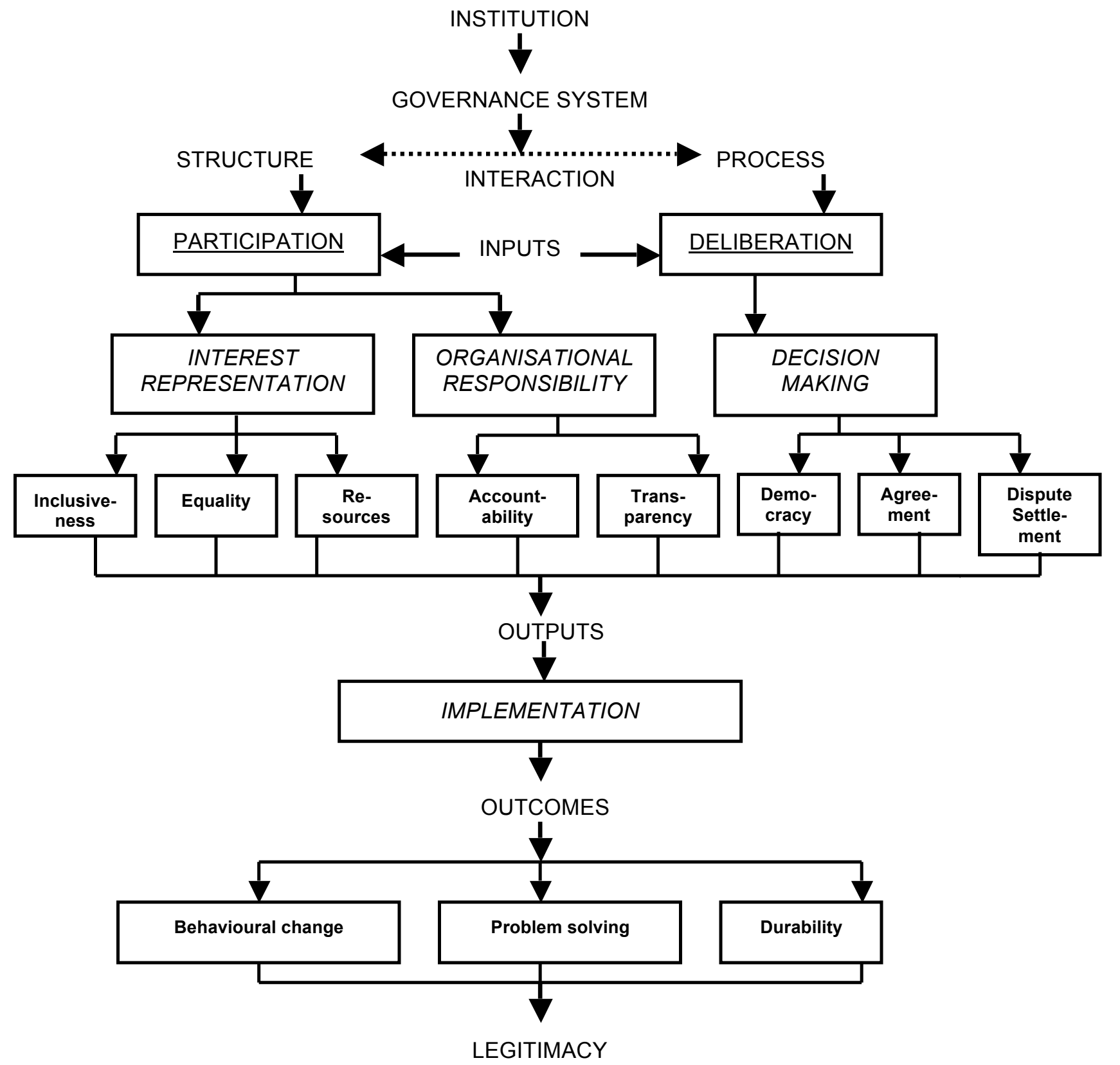

Boxed typeface indicates hierarchical relationship at the PRINCIPLE, CRITERION and Indicator levels. 